one amino acid has little effect. But some proteins much farther away in this space (that is, with many different amino acids), may also have the same function. If you imagine that the space at all these 'neutral variants' is shaded, then the shaded areas make up the original protein's 'neutral space' and indicate the organism's robustness.

My only grumble is that I would have used the word 'domain', as the neutral region is a subregion of the whole protein space, but I hope no great confusion will arise. The author shows clearly that although neutral-space analysis supports old principles of population genetics in several cases, sometimes it does not. Consider, for example, the limited validity of the Haldane-Muller principle, which states that the mutational load depends only on the mutation rate. Mean fitness is found to depend on the robustness of the population, which is actually a function of the structure of the neutral space.

I would like to know more about how the nervous system fits into the framework of Wagner's book. We know from studies ranging from the synapse to cell shape and functional neuroanatomy, for example, that at different scales a great many parts of the brain can have essentially the same function, in line with Wagner's analysis of 'distributed robustness'. But I realize that even the best story must end somewhere and leave space for future ones. Eörs Szathmáry is at the Collegium Budapest, 2 Szentháromság utca, 1014 Budapest, Hungary.

\title{
Psychology in the real world?
}

\section{World As Laboratory: Experiments with \\ Mice, Mazes, and Men \\ by Rebecca Lemov \\ Hill \& Wang: 2005.304 pp. $\$ 30$}

\section{Steve Blinkhorn}

The modern world was created by egg-headed, white-coated scientists working in laboratories, surrounded by complex equipment and inventing ever more ingenious gadgets. That at least is the popular myth of intentional or intelligent design, and there is some truth in it: after all, the laser began as a laboratory curiosity firmly rooted in hard science, but now delivers entertainment to the masses.

Other technologies, arising from theories long since discredited and from scientists whose claims to white-coat status now seem tenuous, have moulded our world more than we realize. What's more, there were shadowy and sometimes sinister sponsors at work promoting and channelling developments that are now ubiquitous and inescapable in Western culture. These are techniques intended to shape behaviour, attitudes and thinking, arising principally from experimental psychology. And they are dangerous. That is the message I take from World As Laboratory, an anthropologist's view of twentieth-century psychological, behavioural and social science.

Rebecca Lemov's avowed focus is on the transfer of laboratory findings to the real world, and on the treatment of the real world as if it were some kind of laboratory. She finds manifest and manifold flaws in this enterprise, which she calls variously "human engineering " and "the American experiment". Her topics range from Jacques Loeb's experiments on tropisms, Elton Mayo's Hawthorne studies and Clark Hull's work on learning in rats, to the American administration of Pacific islands after the Second World War, brainwashing in
IMAGE

UNAVAILABLE FOR COPYRIGHT REASONS
Korea and subsequent work by the CIA, Stanley Milgram's obedience experiments and the Stanford prison experiment.

Much of Lemov's attention is given to the Yale Institute of Human Relations and the Rockefeller funding sources that supported it. Indeed, the extent to which Rockefeller money bankrolled laboratory psychology and allowed favoured schools of thought to flourish in the 1930 s without a care for tomorrow, while most of the world was coping with the Great Depression, was news to me.

"A secret history that's not really a secret any more ${ }^{x}$ is how the dustjacket puff characterizes Lemov's story. Unfortunately it's not really a history either. Her theme encompasses the whole of experimental, social and differential psychology, and more besides, but there is a great deal of selective focus in the tale she tells. The narrative veers from revealing new perspective to radical misconception, with some startling clangers on the way, and great chunks missing. A couple of howlers: on the use of electric shocks in experiments on rats, "the current ranged in intensity from 3.3 amperes to 7.6 volts $^{\mathrm{m}}$; on the use of a tape recorder in the $1950 \mathrm{~s}$, the tape was "running at the standard rate of seven and a half feet per second". There is also a bizarre misreading of history: rat researchers' accomplishments apparently "included the intelligence test, the SAT, the opinion survey, the early poll, the projective test..." (although the development of none of these is described at all). A huge omission, but for a passing reference, is operant conditioning and the work of B. F. Skinner. Such flaws undermine one's confidence in the author's sure-footedness on topics where one has to trust the detail of her account.

On a second reading, it becomes clear where the problem lies: Lemov has failed to get under the skin and into the minds of the characters who populate her narrative, and she has too selective and episodic a view of how psychology and related disciplines developed. It is as if she got her perspective from the sorts of stories that get into newspapers and failed to notice that they are but the tips of icebergs. Whether it is in the potted biographies or her account of laboratory methods, she comes to describe but stays only to scoff. The prevailing tone is one of uncritical pre-modern ethnography: look at this strange tribe and the weird things they got up to.

Empirical psychology arose and developed in contradistinction to prevailing views of the nature of mind, and grasped at emerging technologies both for theoretical models (hydraulic systems, the telephone exchange, the computer) and for laboratory tools. It is not necessary to agree with the theories, be sympathetic to the characters concerned or share their moral standpoint to make sense of what happened. Schools of thought flourished and then failed as their limitations were made manifest, but some left behind effective technical methods that can be used for good or ill, regardless of their theoretical origins. 
It does not help an author attempting to communicate how this affected modern society to have an apparent aversion to technology and mathematics. On Hull's approach to learning theory, for example, she says, "from 1929 to 1936 the mechanisms become increasingly complex, like fine-spun webs". But she does not see that Hull's rather modestly complex work was a remote precursor of modern attempts to create artificial intelligence, and she can scarcely have any acquaintance with the sorts of software models they involve. Hull just didn't have digital computers to play with. ${ }^{\alpha}$ Hull loved logarithms and seems to have had a fetish for mathematics," she remarks. Whether this would be a similarly perverse trait in a quantum physicist I cannot guess, but as most of the attempt to develop scientific psychology has involved elements of quantification, I suppose her objection must be to that enterprise as a whole and in principle. It would be a more persuasive objection if it were based on a clearer, more comprehensive and more penetrating grasp of its target.

Steve Blinkhorn is at Psychometric Research and Development, Brewmaster House, The Maltings, StAlbans AL13HT, UK.

\section{EXHIBITION}

\section{Casting a long shadow}

\author{
Melancholy: Genius and Insanity in the \\ West \\ National Galleries of the Grand Palais in \\ Paris, France, until 16 January 2006 and the \\ Neue Nationalgalerie in Berlin, Germany, \\ from 16 February to 7 May 2006.
}

\section{Laura Spinney}

In Albrecht Dürer's 1514 engraving Melancholy, a winged female creature sits in semidarkness, surrounded by scientific symbols, resting her head on her hand, a pensive expression on her face. It is an image that has been reproduced again and again over the centuries, and it conveys the sense of solitude and depression of the spirit out of which springs both madness and the greatest acts of artistic and scientific invention. Dürer created his image in what might be called the golden age of melancholy', when that state of mind was closely linked with creativity.

The exhibition Melancholy: Genius and Insanity in the West sets out to track the changing attitudes to melancholy over the centuries. It shows how during different epochs it has been claimed by intellectuals, mystics, scientists and artists in turn. The ancient Greeks recognized the power of melancholic genius - what Aristotle called "the melancholy of exceptional men" - but with the arrival of Christianity this state of mind took on a diabolical significance.

The early Christians went out into the desert to wrestle with demons, which often appeared in the form of visions or obsessions. They were occasionally overcome by a kind of spiritual torpor that was regarded as a deadly $\sin$. Medieval thinkers saw no creative energy in melancholy, and it was during the Middle Ages that the contemplative state was first associated with mania in the form of disturbing visions. This can be seen in Hiëronymus Bosch's painting The Temptation of St Anthony and is reflected in our modern diagnosis of bipolar depression.

The Greeks attributed melancholy to the spleen and black bile. Autumn was its season, dusk its time of day, earth its element and Saturn its planet. After the Renaissance, the progressive Florentines resurrected melancholy as a source of divine inspiration, and in Dante's The Divine Comedy it was from the sphere of Saturn that the poet saw the dazzling golden ladder that led upwards to contemplation of the deity.

The children of Saturn eventually came to include all social outcasts as well as people of melancholic temperament, and one of the themes in the exhibition is the loneliness of the monster. Goya's painting Colossus depicts a ghostly figure who strides over the landscape and the terrified, fleeing peasants; Charles Le Brun drew men resembling wolves; and the werewolf itselfhas a long association with

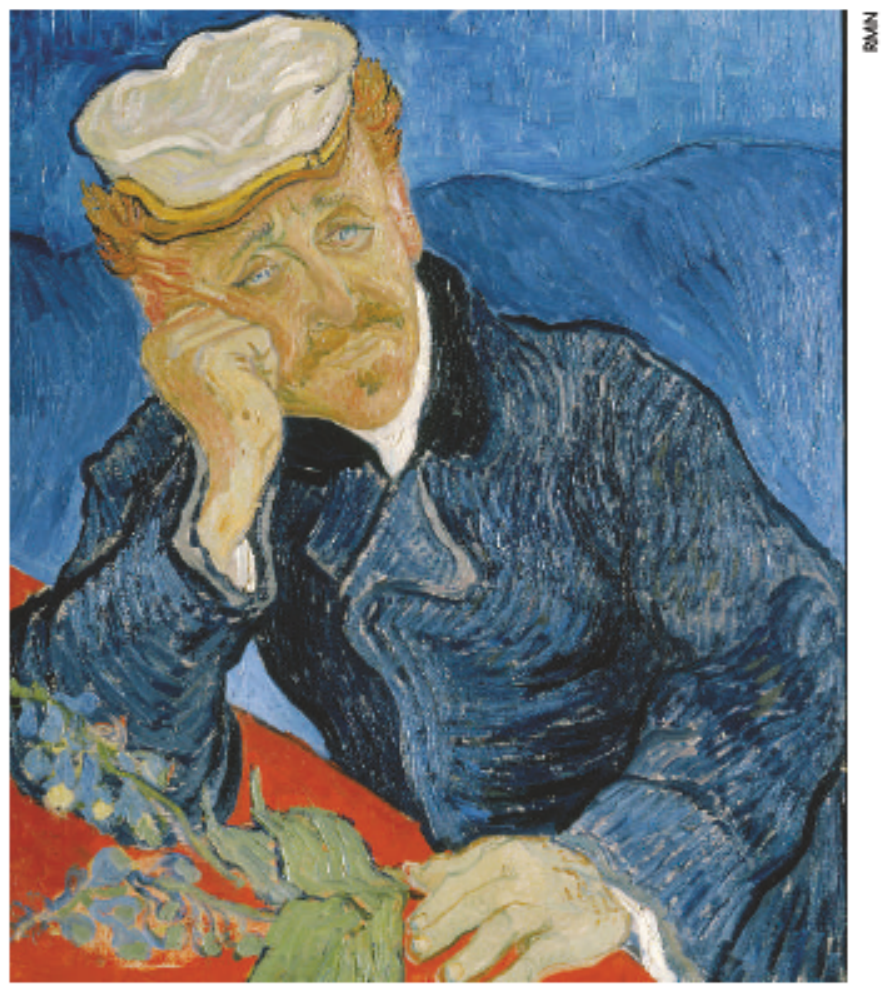

A picture of melancholy: Van Gogh's Partrait of Dr Gachet.

melancholy. William Blake's Nebuchadnezzar from the painting of the same name is half man, half beast. Mad, naked and solitary, he crawls into a cave, fleeing the sun. The melancholic landscape is often bare and dotted with ruins. In the seventeenth century, Cervantes created the melancholic dreamer Don Quixote, but melancholy soon came to be seen as an affliction of island peoples, particularly the British.

Only music could reach the soul of the melancholic and lift his spirit, so David played his harp to soothe the disturbed King Saul. In Fernand Khnopff's painting Listening to Schumann, a woman whose face is hidden by her hand seems marooned as she sits in the centre of a drawing room, dressed in black, bathed in a sombre, late afternoon light. Schumann himself suffered from depression and eventually committed suicide.

With the arrival of the eighteenth century and the Enlightenment, the medical and artistic interpretations of melancholy diverged. In the world of science and rational thought, melancholy came to signify irrationality and madness. The medical diagnosis monomania was used to describe the obsessive aspect of mania, and was later replaced by the broader diagnosis of bipolar depression, which covered both the manic and the depressive poles of the condition. To artists, in contrast, melancholy Portrait of Dr Gachet combines both interpretations. The artist's model studied melancholy at the Pitié-Salpetrière hospital in Paris, and in the painting adopts the time-honoured pose of the wistful melancholic, head on hand. Meanwhile Ron Mueck's larger-than-life sculpture of a naked man cowering in a corner, chin in hand, speaks strongly of the asylum.

Science no longer has any use for the concept of melancholy, and the most widely accepted meaning now is the artistic one, what Victor Hugo described as "more than gravity and less than sadness". The modern concept of melancholy seems to be best summed up by Giorgio de Chirico's painting from 1912 showing a tomb bearing the marble figure of a reclining woman who rests her head on her hand. The tomb has engraved on it the word melanconia, and it casts a long, long shadow.

Laura Spinney is a freelance writer based in London and Paris. suggested solitude and meditation. Van Gogh's 